\title{
Peculiarities of the supervision of vascular catheters
}

\author{
Zyta Kuzborska ${ }^{1}$, Zita Gierasimovič ${ }^{2}$ \\ ${ }^{1}$ Vilnius Gediminas Technical University, Lithuania \\ ${ }^{2}$ Vilnius University, Lithuania \\ E-mails: ${ }^{1}$ zyta.kuzborska@vgtu.lt (corresponding author), ${ }^{2}$ zitagieras@gmail.com \\ (Received 22 February 2016; accepted 22 April 2016)
}

\begin{abstract}
The article analyses the supervision of vascular catheters, as well as the factors influencing the complications that occur. The method of observation was applied to assess the supervision of catheters, sample size target. The patients were assessed by gender, age, changes in their state of health, the type of vascular catheters and the assessment of dressing. It was established that the following physical (the condition of skin and the dressing, place and duration of the insertion of a catheter) and mechanical (catheter displacement of vascular injection local tissue stretching for biological fluids stay) factors were of great significant.
\end{abstract}

Keywords: supervision of vascular catheters, risk factors, complications.

\section{Introduction}

Through a catheter medication gets directly into the central circulation of the blood where it dissolves quickly and spreads all over the organism [1]. Complications that occur due to a vascular catheter insertion depend on the following factors; anatomical deformation of the body in the place of a catheter insertion; the condition of the patient; the skills and knowledge of the staff [2]. The early complications are bleeding, haematoma, the improper position of the catheter [3]. Catheterrelated sepsis, thrombosis, tissue extravasations and infection are the cause of late complications. [4]. The improper localisation of the catheter with respect to vein projection is the course of health problems of the patient and his/her heart rhythm disorders (arrhythmia) [5]. In case the rules of aseptic are not observed, the patients with involuntary bowel movement and urination problems are subject to a greater risk of infection [6]. Other authors state that the course of infection is artificial lung ventilation, the patient's old age, the use of immunosuppressive medication [7, 8]; practical training of the staff decreases the incidence of vascular catheter-related infections in from 3.29 to 2.36 cases [9]. The incidence of vascular catheter-related infections established in Lithuania is from 9.3 to 2.7 cases [10]. According to the data presented in literature, places of the insertion of vascular catheters are complicated with respect to infection, the place of catheter insertion projection is inconvenient on account of possible injury of the surrounding tissues [2, $10]$, and the group of the patients who are old and have adjacent diseases are particularly prone to complications [12].

Swelling and reddening of the place of the vascular catheter insertion, as well as pain in it, is a local complication $[11,12]$.

The aim of this work is to assess the peculiarities of the supervision of vascular catheters in the reanimation and intensive care units.

\section{Methods}

A total of 104 patients were under observation in one of the hospitals in Vilnius who underwent treatment in the reanimation and intensive care units in 2014. The method of observation was used to assess the supervision of vascular catheters, sample size target. The research data were encoded and analysed by means of the programme IBM SPSS Statistics 19.0. Methods of descriptive statistics were applied, and the characteristics of the samples were calculated: the average, the median and the percentage. Differences between non-parametric indicators were established by

(C) 2016 The Authors. Published by VGTU Press. This is an open-access article distributed under the terms of the Creative Commons Attribution License (CC-BY 4.0), which permits unrestricted use, distribution, and reproduction in any medium, provided the original author and source are credited. 
means of the Fisher's $\chi^{2}$ (chi square) criterion. The relationship between the independent variable and the dependent variable was considered to be statistically significant when $p \leq 0,05$.

\section{Results}

$53.8 \%$ (56) of males and $46.5 \%$ (48) of females between the ages of 30 and 71 years and older underwent treatment at the intensive care units in 2014. The average age of the patients was as follows: 63.1 years \pm 12.9 years. The duration of the patient's treatment is as follows: 5.25 days \pm 7.5 days, minimum one day, maximum 50 days, the median is three days. From that number $57.7 \%$ (60) of the patients had a peripheral vascular catheter inserted, and 91.3\% (95) of the patients had a central vascular catheter. In assessing the condition of the patients' skin the place of the insertion of a vascular catheter, it was established that a change in the patient's skin condition depended on the patient's behaviour, that is, if the patient was self-contained, did not toss, was quiet, did not try to take out the inserted catheter by himself/herself, no cases of complications were observed $(\mathrm{p}<0.05)$ (Table 1). The risk factors which influence changes in the skin in the place of the insertion of a vascular catheter have been established $(\mathrm{p}<0.05)$ (Table 2).

Table 1. Skin condition in the placers of the insertion of catheters

\begin{tabular}{|c|c|c|c|c|c|c|c|c|}
\hline \multirow{4}{*}{$\begin{array}{l}\text { Vascular } \\
\text { catheter }\end{array}$} & \multirow{2}{*}{$\begin{array}{l}\text { Assessment } \\
\text { of skin } \\
\text { condition }\end{array}$} & $\begin{array}{l}\text { Patient is } \\
\text { self- } \\
\text { contained }\end{array}$ & $\begin{array}{l}\text { Patient is } \\
\text { partly self- } \\
\text { contained }\end{array}$ & $\begin{array}{l}\text { Patient is } \\
\text { not self- } \\
\text { contained }\end{array}$ & Total & \multirow{2}{*}{$\chi^{2}$} & \multirow{2}{*}{ df } & \multirow[b]{2}{*}{$\mathrm{p}$} \\
\hline & & $\begin{array}{c}\text { Abs. } \\
\text { number } \\
(\%)\end{array}$ & $\begin{array}{c}\text { Abs. } \\
\text { number } \\
(\%)\end{array}$ & $\begin{array}{c}\text { Abs. } \\
\text { number } \\
(\%)\end{array}$ & $\begin{array}{c}\text { Abs. } \\
\text { number } \\
(\%)\end{array}$ & & & \\
\hline & $\begin{array}{l}\text { Skin is } \\
\text { injured }\end{array}$ & 3 (17.6) & $18(41.9)$ & $22(62.9)$ & $43(45.3)$ & \multirow{2}{*}{9.807} & \multirow{2}{*}{2} & \multirow{2}{*}{$\begin{array}{l}0.007^{*} \\
0.007^{*}\end{array}$} \\
\hline & $\begin{array}{l}\text { Skin is not } \\
\text { injured }\end{array}$ & $14(82.4)$ & $25(58.1)$ & $13(37.1)$ & $52(54.7)$ & & & \\
\hline
\end{tabular}

Note: $*$ - statistically significant figure $\mathrm{p} \leq 0.05$

Two types of dressing are used in supervising vascular catheters, which protect the place of the insertion of a catheter: breathable, adhesive coated polyurethane film dressing Tegaderm and cloth dressing Mesoft. It was established by investigations that Tegaderm dressing remains unsoiled by biological liquid 1.5 times longer, and Mesoft dressing has to be changed 5 times more often than the polyurethane dressing. The cloth dressing when soaked with blood/biological liquid came off 6 times more often than flexible polyurethane dressings which become adjusted in places which are difficult to dress and protect them from external pollution.

Table 2. Risk factors influencing the patient's skin condition in the places of the insertion of a vascular catheter

\begin{tabular}{|c|c|c|c|c|c|c|c|}
\hline $\begin{array}{c}\text { Adjacent } \\
\text { diseases of the } \\
\text { patient }\end{array}$ & $\begin{array}{l}\text { Lesions exist } \\
\text { Abs. number } \\
\text { (\%) }\end{array}$ & $\begin{array}{l}\text { No lesions } \\
\text { Abs. } \\
\text { number (\%) }\end{array}$ & $\begin{array}{c}\text { Total } \\
\text { Abs. number } \\
(\%)\end{array}$ & OR (PI) & $\chi^{2}$ & df & $\mathrm{p}$ \\
\hline Lesions (exist) & $3(7.0)$ & $1(1.9)$ & $4(4.2)$ & \multirow{2}{*}{$\begin{array}{c}3.86 \\
(0.38-38.18)\end{array}$} & \multirow{2}{*}{1.490} & \multirow{2}{*}{1} & 0.222 \\
\hline (No) lesions & $40(93.0)$ & $51(98.1)$ & $91(95.8)$ & & & & $0.325^{*}$ \\
\hline $\mathrm{CD}$ (exist) & $14(32.6)$ & $9(17.3)$ & $23(24.2)$ & \multirow{2}{*}{$\begin{array}{c}2.31 \\
(0.88-6.03)\end{array}$} & \multirow{2}{*}{2.98} & \multirow{2}{*}{1} & 0.084 \\
\hline $\mathrm{CD}$ (no) & $29(67.4)$ & $43(82.7)$ & $72(75.8)$ & & & & $0.097 *$ \\
\hline
\end{tabular}

Note: $*$ - statistically significant figure $\mathrm{p} \leq 0.05$

\section{Discussion and acknowledgements}

When analysing the results obtained it was established that nursing actions for the supervision of central catheters $45.3 \%$ (43) and the supervision of peripheral catheters $57.1 \%$ (12) were applied. To avoid cases of complications skin around the place of the insertion of catheters was 
watched and catheters were held in carrying out treatment or nursing interventions, as well as in changing the dressing.

The following nursing measures were applied in the supervision of vascular catheters in the reanimation and intensive care units: the condition of the skin and dressing, around the place of the insertion of a vascular catheter was assessed; such mechanical actions as pushing the permanent place of the insertion of a vascular catheter, the presence of infection in the place of the insertion of catheters, soaking of the bandage with blood and biological liquid increase the number of cases of complications.

\section{References}

[1] Budginaitė, R.; Sinkevič, V.; Zagrebnevienè, G. 2013. Infekciju, susijusiu su kraujagysliu kateteriu naudojimu, profilaktikos metodinès rekomendacijos [online]. Užkrečiamujjų ligų ir AIDS centras [cited 22 February 2016]. Available from Internet: http://www.ulac.lt/uploads/downloads/leidiniai/m_r_\%20kateteriai.pdf

[2] Strainys, T., et al. 2012. Evaluation of the main pathogens and risk factors for catheter associated sepsis in chronic hemodialysis patients, Theory and Practice in Medicine 18(4.2): 534-538.

[3] Valintèlienè, R.; Gailienè, G.; Beržanskytè, A. 2012. Prevalence of healthcare-associated infections in Lithuania, Journal of Hospital Infection 80(1): 25-30. http://dx.doi.org/10.1016/j.jhin.2011.09.006

[4] Kalibatienè, D.; Černiauskaitè, I. 2011. Centrinių venos kateterių naudojimas ir priežiūra reanimacijos ir intensyviosios terapijos skyriuose, Slauga. Mokslas ir praktika 170: 14-18.

[5] Schweickert, W. D., et al. 2009. A randomized, controlled trial evaluating postinsertion neck ultrasound in peripherally inserted central catheter procedures, Critical Care Medicine 37(4): 12171221. http://dx.doi.org/10.1097/CCM.0b013e31819cee7f

[6] Froehlich, C. D., et al. 2009. Ultrasound-guided central venous catheter placement decreases complications and decreases placement attempts compared with the landmark technique in patients in a pediatric intensive care unit, Critical Care Medicine 37(3): 1090-1096. http://dx.doi.org/10.1097/CCM.0b013e31819b570e

[7] Zarb, P., et al. 2012. The European Centre for Disease Prevention and Control (ECDC) pilot point prevalence survey of healthcare-associated infections and antimicrobial use, Eurosurveillance 17(46): 20316.

[8] Galpern, D., et al. 2008. Effectiveness of a central line bundle campaign on line-associated infections in the intensive care unit, Surgery 144(4): 492-495. http://dx.doi.org/10.1016/j.surg.2008.06.004

[9] O'Grady, N. P., et al. 2011. Guidelines for the prevention of intravascular catheter-related infections, Clinical Infectious Diseases 52(9): e162-e193. http://dx.doi.org/10.1093/cid/cir257

[10] Ašembergienè, J., et al. 2013. Nosocomial infections in the intensive care units in Lithuania: results of the national nosocomial surveillance system, 2009-2011, Visuomenes sveikata 60: 58-66.

[11] Berezhanski, B. V.; Zhevnerev, A. A. 2006. Catheter-associated bloodstream infections, Diseases and Pathogens 8(2): 130-144.

[12] Gulbinas, A.; Barauskas, G. 2007. Central venous catheters in the prevalence of nosocomial infection study, Lithuanian Surgery 5(2): 181. 